\section{ENHANCEMENT STRATEGY OF METHANE PRODUCTION FROM ANAEROBIC DIGESTION START-UP PROCESS OF GREASE TRAP WASTE}

\author{
Nazaitulshila Rasita*, Azni Idrisb, Wan Azlina Wan Ab Karim Ghanib \\ aSchool of Ocean Engineering, Universiti Malaysia Terengganu \\ (UMT), 21030, Kuala Nerus, Terengganu, Malaysia. \\ bDepartment of Chemical Engineering, Faculty of Engineering, \\ Universiti Putra Malaysia (UPM), 43400, Serdang, Selangor Darul \\ Ehsan, Malaysia
}

Article history

Received

6 April 2017

Received in revised form

2 July 2017

Accepted

10 September 2017

*Corresponding author nazaitulshila@umt.edu.my

\begin{abstract}
Anaerobic digestion is one of the potential processes of waste lipid recovery for beneficial use to produce methane $\left(\mathrm{CH}_{4}\right)$. In anaerobic digestion, the utilization of grease trap waste for mono digestion is less reported. This might be due to high lipid content in grease trap waste that may cause inhibition effects which resulted from long chain fatty acids (LCFA) accumulation during the degradation process. This study is intended to investigate the effects of lipid acclimated biomass (LAB) and non-acclimated biomass (NAB) in the anaerobic treatment of grease trap waste over increasing organic loading rate (OLR) in continuous stir tank reactor. The results showed that the resistance of grease trap waste toxicity was higher in LAB while in inhibited reactor (NAB), 9 days lag phase occurred during the start-up process and affected the overall $\mathrm{CH}_{4}$ production. At OLR of $2.2 \mathrm{gCOD} / \mathrm{L}$.day, high $\mathrm{CH}_{4}$ was yielded of $0.22 \mathrm{LCH}_{4} / \mathrm{gCOD}$ removed at standard temperature and pressure with $11 \% \mathrm{CH}_{4}$ enhancement in LAB. The inoculum acclimatization is one of the strategy to improve $\mathrm{CH}_{4}$ production and the purpose is to provide favorable condition to the methanogens towards build-up of volatile acids and inhibitive components such as LCFA. Thus, the overall enhancement for acclimated to LCFA inoculum strategy was $42 \%$. The induction during the start-up had promoted and enhanced $\mathrm{CH}_{4}$ production when semi-continuous feeding was introduced and remain higher than the other reactors throughout the entire experiment. This indicates that the use of biomass consortium acclimated to long chain fatty acids compounds is a reliable strategy to speed up the start-up of anaerobic digestion process and to enhance the overall $\mathrm{CH}_{4}$ yield.
\end{abstract}

Keywords: Grease trap waste, anaerobic, long chain fatty acids, acclimatization, methane

\begin{abstract}
Abstrak
Pencernaan anaerob adalah salah satu proses pemulihan sisa lemak untuk kegunaan bermanfaat bagi menghasilkan metana $\left(\mathrm{CH}_{4}\right)$. Dalam pencernaan anaerob, penggunaan sisa perangkap gris untuk pencernaan mono kurang dilaporkan. Ini mungkin disebabkan oleh kandungan lemak yang tinggi dalam sisa perangkap gris boleh menyebabkan kesan perencatan yang mengakibatkan pengumpulan asid lemak rantaian panjang (LCFA) semasa proses degradasi. Kajian ini bertujuan untuk mengkaji kesan-kesan biomas diaklimatisasi terhadap lemak (LAB) dan biomas yang tidak diaklimatisasi (NAB) dalam rawatan anaerobik sisa perangkap gris bagi peningkatan kadar beban organik (OLR) dalam reaktor teraduk berterusan. Keputusan menunjukkan bahawa ketahanan terhadap ketoksikan sisa perangkap gris lebih tinggi dalam LAB sementara di dalam reaktor yang mengalami perencatan (NAB), fasa sela 9 hari berlaku semasa proses permulaan dan menjejaskan pengeluaran $\mathrm{CH}_{4}$ secara keseluruhan. Pada OLR $2.2 \mathrm{gCOD} / \mathrm{L}$.hari, $\mathrm{CH}_{4}$ tinggi dihasilkan dengan $0.22 \mathrm{LCH}_{4} / \mathrm{gCOD}$ disingkikan pada suhu dan tekanan standard dengan penambahan $11 \% \mathrm{CH}_{4}$ dalam $\mathrm{LAB}$. Penyesuaian inokulum adalah salah satu strategi untuk meningkatkan pengeluaran $\mathrm{CH}_{4}$ dan tujuannya adalah untuk menyediakan keadaan yang baik kepada metanogen terhadap pembentukan asid yang tidak menentu dan komponen-komponen yang merencat seperti LCFA. Oleh itu, peningkatan keseluruhan untuk strategi inokulum diaklimatisasi terhadap LCFA adalah $42 \%$. Induksi semasa permulaan telah mempromosikan dan meningkatkan pengeluaran $\mathrm{CH}_{4}$ apabila pemakanan separa berterusan diperkenalkan dan kekal lebih tinggi daripada reaktor-reaktor lain sepanjang keseluruhan eksperimen. Ini menunjukkan bahawa penggunaan konsortium biomas diaklimatisasi terhadap sebatian asid lemak rantaian panjang adalah strategi yang boleh dipercayai untuk mempercepatkan proses pencernaan anaerobik dan meningkatkan kadar $\mathrm{CH}_{4}$ secara keseluruhan.
\end{abstract}

Kata kunci-Sisa perangkap minyak, anaerob, asid lemak rantaian panjang, diaklimatisasi, metana

(c) 2017 Penerbit UTM Press. All rights reserved 


\subsection{INTRODUCTION}

In anaerobic digestion, the consumption of organic matters that have high lipid content is less favorable option to be used as a substrate. During hydrolysis stage, lipid is basically consists of triglyceride es and degraded by hydrolytic bacteria to break the chemical bond to produce fatty acids (long chain fatty acids, LCFAs) and organic acids [1]. The intermediate produced during degradation is sensitive to anaerobes bacteria due to restriction of adsorption onto bacteria cell wall that being coated by LCFAs $[2,3]$. The limiting factors of LCFAs inhibition had caused transport limitation for cell wall adsorption and reduce it solubility thus causes several operational problems in anaerobic system treating relatively high lipid content substrate [4-5]. Despite the abovementioned risks, lipid is tested to have high biodegradability and potential to produce more methane compared to protein or carbohydrates through the catalytic in the process done by acidogenic bacteria $[1,6]$. As the consequences, exploitation of waste containing high lipid content are becoming more attractive sources in producing biogas from anaerobic treatment system.

Different strategies have been implementing to overcome the inhibitive factors caused by LCFAs and one of the strategies is by selecting appropriate inoculum source refers to lipid acclimated biomass. The purpose is to provide favorable condition to the methanogens towards build-up of volatile acids and inhibitive components [4]. In batch assays tested, a biochemical methane potential study using acclimated inoculum to lipid which obtained from municipal sludge anaerobic digester fed with lipid on daily basis were used. The inoculum was known to be acclimatized to lipid when the content of fatty acid were observed in the inoculum characterization. The study were tested on oily food waste as a substrate and the findings showed initial 10 days of lag phase was recorded in non-adapted inoculum while in adapted inoculum assays showed highest biomethanation values without experienced of lag phase [2]. An increment of $2 \%$ of methane composition was observed when acclimated inoculum to lipid was used in the treatment of waste vegetable oils [7]. Goncalves et al. (2012) performed batch experiment to evaluate the inhibitory effect of olive mill wastewater reported that inhibition occurred during start-up process in non-adapted inoculum as low as loading of $5 \mathrm{gCOD} / \mathrm{L}$.d while in adapted assay, no inhibition occurred even at highest loading of $25 \mathrm{gCOD} / \mathrm{L} . \mathrm{d}$.

Since the most significant phase during anaerobic digestion is during start-up, it is important to ensure the relevant adaptation of the system to the influent capacity to avoid digester failure [8]. Numerous studies have been conducted to determine the performance of anaerobic treatment using acclimated biomass is based on batch assays accomplished with lipid-based synthetic substrate [9-
11]. Less attention is given on using acclimated biomass onto actual effluents in continuous stir tank reactor (CSTR). Furthermore, lack of information regarding the individual patterns of LCFAs degradation during inhibition and stable operation of reactors treating grease trap waste (GTW). Thus, the purpose of this work is to determine the potential of anaerobic digestion of GTW in enhancing methane production by studying the effects of using acclimated biomass to LCFAs in CSTR with increasing organic loading rate (OLR).

\subsection{METHODOLOGY}

Two reactors were used with different inoculum known as lipid acclimated biomass (LAB) and nonacclimated biomass (NAB). Glass reactors with working volume of $1 \mathrm{~L}$ were used and both reactors were equipped with water jacketed to sustain required temperature for the entire processes. The reactor is fitted with a top stainless steel plate with attached stirrer, feeding and sampling port, gas sampling port, $\mathrm{pH}$ probe, thermocouple and acid and alkaline port. A control unit is used to monitor the $\mathrm{pH}$ and temperature. The produced biogas was collected in a 5 L Tedlar gas sampling bag and analyzes using GC-TCD Gas Chromatography.

Anaerobic digested sludge was collected from palm oil mill anaerobic sludge (POMS) obtained from Felda Serting Hilir Palm Oil Mill Plant. POMS produced from anaerobic treatment process of palm oil mill effluent are known to contain low level of oil and grease (less than $0.18 \mathrm{~g} / \mathrm{L}$ ) [12]. As shown in Table 1, palmitate was the only fatty acid detected in low level in POMS. Thus, in this study POMS collected was designated as non-acclimated biomass (NAB). To impose lipid acclimated biomass (LAB) to the process, preparation was made according to [13] by exposing POMS through prolonged contact with lipid mixture, consisting of sodium palmitate (C16:0), sodium stearate (C18:0) and sodium oleate (C18:1) in a mixture of 30:20:50 (w/w/W), respectively. The LCFA mixture simulated the main constituents in GTW [14]. GTW was sampled from centralized grease trap of food service establishment in Putrajaya, Malaysia. Table 1 shows the characterization of $\angle A B, N A B$ and GTW used in the study. Biomass in LAB has been adapted to lipid when most of the lipid content was detected compared to NAB when only the content of palmitate could be detected. Thus, biomass in LAB is considered as acclimatized inoculum to lipid. Although the LAB contained palmitic content but the value is lower than the GTW and is considered to not affect the overall process [15]. 
Table 1 Characterization of NAB, LAB and GTW

\begin{tabular}{|c|c|c|c|c|}
\hline Parameters & Unit & $\begin{array}{l}\text { Non- } \\
\text { acclimated } \\
\text { biomass } \\
\text { (NAB) }\end{array}$ & $\begin{array}{l}\text { Lipid } \\
\text { Acclimated } \\
\text { biomass } \\
\text { (LAB) }\end{array}$ & $\begin{array}{l}\text { Grease } \\
\text { Trap } \\
\text { Waste } \\
\text { (GTW) }\end{array}$ \\
\hline $\mathrm{pH}$ & - & $\begin{array}{l}7.35 \\
\pm 0.01\end{array}$ & $\begin{array}{l}6.94 \\
\pm 0.01\end{array}$ & $\begin{array}{l}1.17 \pm \\
0.06\end{array}$ \\
\hline TS & $\mathrm{g} / \mathrm{L}$ & $\begin{array}{l}10.45 \\
\pm 0.04\end{array}$ & $\begin{array}{l}12.12 \\
\pm 0.05\end{array}$ & $\begin{array}{l}0.85 \pm \\
0.19\end{array}$ \\
\hline VS & $\mathrm{g} / \mathrm{L}$ & $\begin{array}{l}4.86 \\
\pm 0.04\end{array}$ & $\begin{array}{l}6.32 \\
\pm 0.04\end{array}$ & $\begin{array}{l}0.82 \pm \\
0.04\end{array}$ \\
\hline COD & $\mathrm{g} / \mathrm{L}$ & $\begin{array}{l}39.53 \\
\pm 0.13\end{array}$ & $\begin{array}{l}23.54 \\
\pm 0.11\end{array}$ & $\begin{array}{l}12.83 \pm \\
0.11\end{array}$ \\
\hline Lipid content: & & & & \\
\hline $\begin{array}{l}\text { Myristate } \\
\text { C14:0 }\end{array}$ & $\mathrm{mg} / \mathrm{L}$ & n.d & 0.78 & 19.5 \\
\hline $\begin{array}{l}\text { Palmitate } \\
\text { C16:0 }\end{array}$ & $\mathrm{mg} / \mathrm{L}$ & 3.81 & 12.23 & 249.8 \\
\hline $\begin{array}{l}\text { Palmitoleate } \\
\text { C16:1 }\end{array}$ & $\mathrm{mg} / \mathrm{L}$ & n.d & 1.09 & 29.1 \\
\hline $\begin{array}{l}\text { Stearate } \\
\text { C18:0 }\end{array}$ & $\mathrm{mg} / \mathrm{L}$ & n.d & 4.82 & 158.4 \\
\hline $\begin{array}{l}\text { Oleate } \\
\text { C18:1 }\end{array}$ & $\mathrm{mg} / \mathrm{L}$ & n.d & 24.11 & 536.6 \\
\hline $\begin{array}{l}\text { Linoleate } \\
\text { C18:2 }\end{array}$ & $\mathrm{mg} / \mathrm{L}$ & n.d & 0.20 & 6.6 \\
\hline
\end{tabular}

"not detected

During start-up, the adaptation of biomass was allowed to acclimatize with GTW in batch mode for both reactors before semi-continuous feeding started. At this phase, the monitoring of $\mathrm{pH}$, alkalinity, chemical oxygen demand (COD), volatile fatty acids (VFA) and LCFAs were measured daily (results not shown except LCFAs). The reactants volume was kept constant and monitored until COD removal measurement was consistent for 3 consecutive days. This has been demonstrating as an acceptable method for anaerobic reactor start-up to maintain the population of active methanogens in performing methanogen activities when higher organic loading was introduced in semi-continuous phase [16].

After the start-up process, the operation of both reactors was switched to semi-continuous feeding mode with increasing OLR (1.3-3.6 gCOD/L.day). The increment of organic loading rate was achieved by increasing the influent flow rate. Both reactors were fed once per day according to the required influent flow rate. The stability and performance of each stage of the reactors were monitored in terms of $\mathrm{pH}$, total alkalinity and effluent volatile fatty acids until steady state condition. Steady state condition is specified by consistent value of COD, TS, VS and $\mathrm{pH}$ concentrations for 3 consecutive days. After stabilized reactors were achieved, new increasing OLR was introduced.

\subsection{RESULTS AND DISCUSSION}

\subsection{Start-up Operation}

In this study, the first 14 days of reactors operation was functioned as a start-up phase. The duration of start-up phase was determined according to the changes of COD removal efficiencies were less than $15 \%$ in 3 consecutive days. This condition can be reflected by the stability of volatile acid to alkalinity ratio and increment of the methane production before any increment of organic loading rate can be introduced into the reactor [8]. Performance of GTW anaerobic treatment using acclimated (LAB) and non-acclimated inoculum (NAB) inoculum sources were determined based on methane composition, methane production rate and methane yield as depicted in Figure $1(a, b, c)$.

It can be seen that the foremost difference between methane composition in $\angle A B$ and $N A B$ occurred during the start-up stage. For $L A B$, methane production increase immediately while in $N A B$ methane production starts slowly with a lag phase of 9 days was recorded and methane production starts to increase rapidly on day 10 . A lag phase was observed in NAB indicated that inhibition was occurred due to acclimatization process in the beginning of the process.

(a)

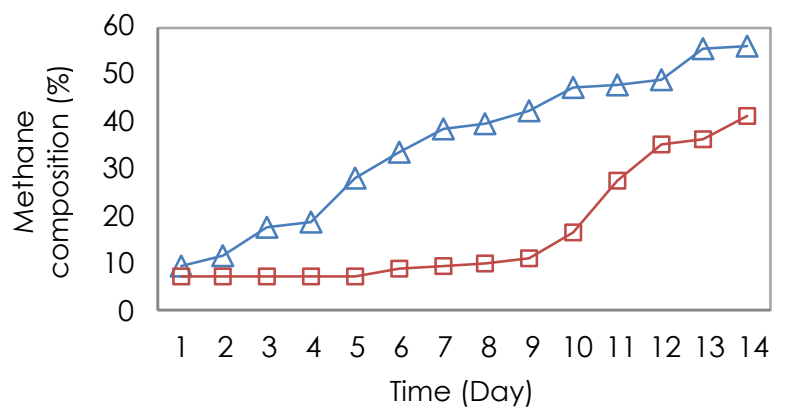

(b)

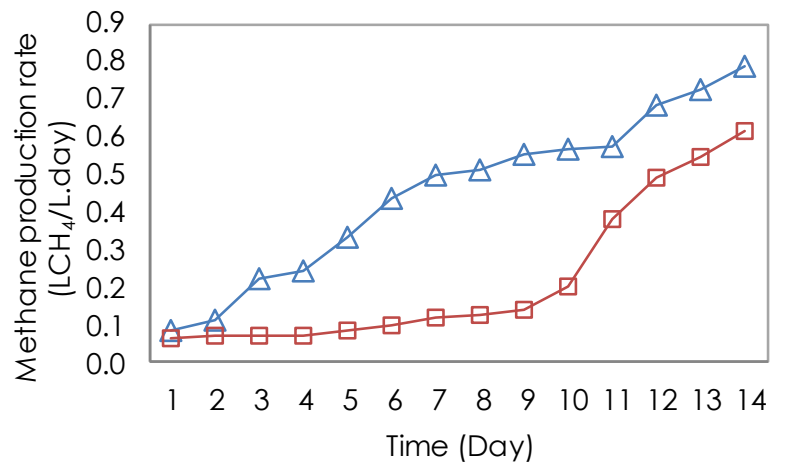


c)

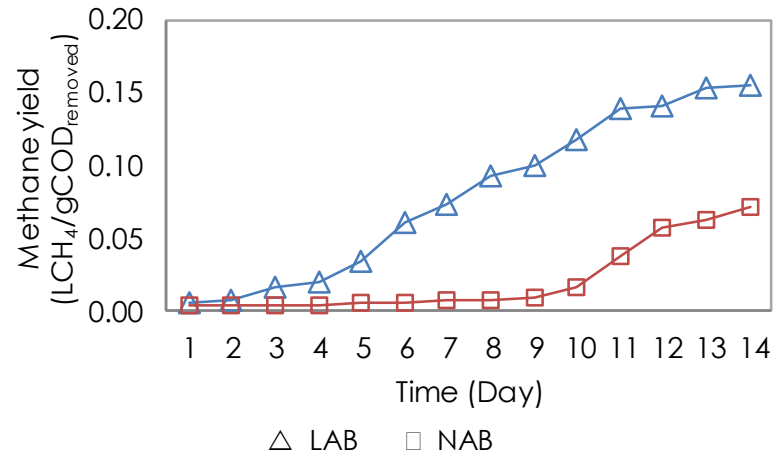

Figure 1 The profile of (a) methane composition; (b) methane production rate and; (c) methane yield of NAB and LAB during start-up operation

On day 14, methane composition for $L A B$ reached a value of $56 \%, 15 \%$ higher than that of for NAB. A similar trend as methane composition were showed by methane production rate and methane yield for both reactors. $L A B$ and $N A B$ recorded highest volumetric methane production rate of 0.078 $\mathrm{LCH}_{4} / \mathrm{L}$ and $0.061 \mathrm{LCH}_{4} / \mathrm{L}$, respectively. While for methane yield, a value of $0.22 \mathrm{LCH}_{4} / \mathrm{gCOD}$ removed and $0.10 \mathrm{LCH}_{4} / g C O D_{\text {removed }}$ were recorded for LAB and $N A B$, respectively. These finding observed similar trend as reported by Neves et al. (2010) where methane production was $16 \%$ higher was evaluated in acclimated reactor as compared to nonacclimated reactor during initial stage of experiments [15]. A lag phase of 10 days was also recorded in non-acclimated reactor treating oily waste from can fish processing industry.

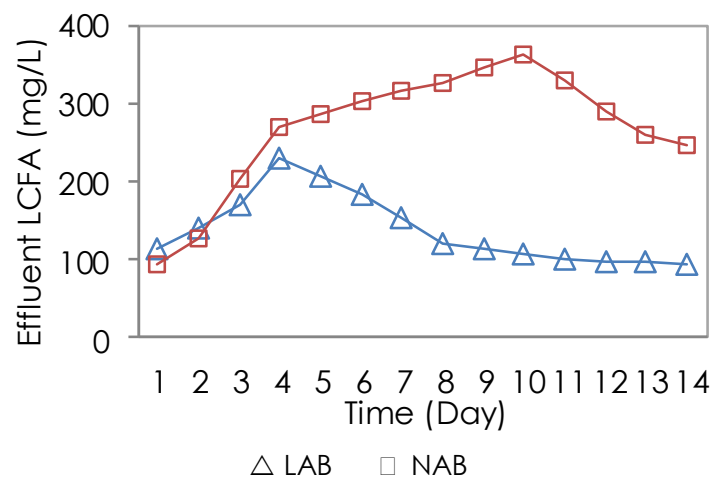

Figure 2 The profile of effluent LCFA of NAB and $L A B$ during start-up operation

Significant differences of LCFAs accumulation between $N A B$ and $L A B$ reactors were recorded as depicted in Figure 2 and higher concentration of LCFAs was observed in NAB reactor for the start-up process. This indicate that LCFAs were accumulated more in NAB as compared to LAB. Highest LCFA accumulation in $L A B$ was recorded on day 4 with the maximum value of $228.31 \mathrm{mg} / \mathrm{L}$ and gradually decreases after that until become stable towards the end of the start-up process. However, in NAB, the accumulation of LCFAs was increased until day 10 with value of $361.54 \mathrm{mg} / \mathrm{L}$. Longer acclimatization time is needed in NAB due to non-acclimated inoculum to LCFAs was used in the reactor. Thus, the result indicated that the initial lag phase observed during the start-up process in NAB could be attributed to the rapid LCFA build up as proposed by Cavaleiro et al. (2008) [17]. In batch assay treating suspended sludge and dairy wastewater, a lag phase of 42 days was observed when the concentration of LCFA accumulated recorded up to $900 \mathrm{mg} / \mathrm{L}$ and no methane production was observed when exceeding this value [17]. In batch assay treating granular sludge with oleic acid, the addition of $100 \mathrm{mg} / \mathrm{L}$ oleic acid had reduced approximately $80 \%$ of methane yield observed with experienced of 13 days lag phase caused by accumulation of intermediate (palmitate and stearate) in LCFA degradation [15].

(a)

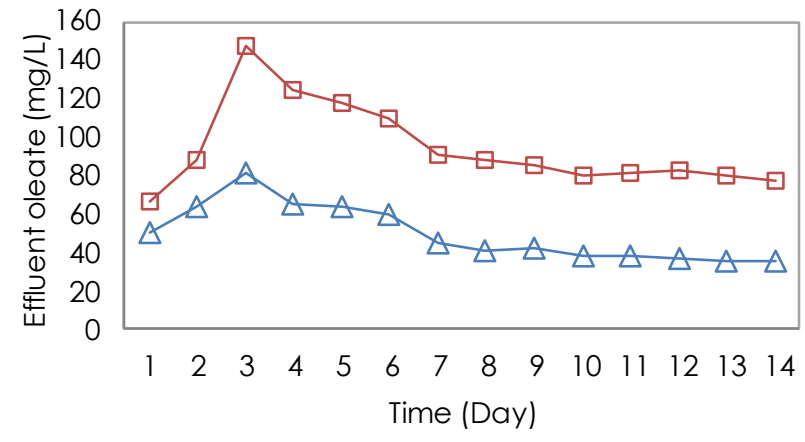

(b)

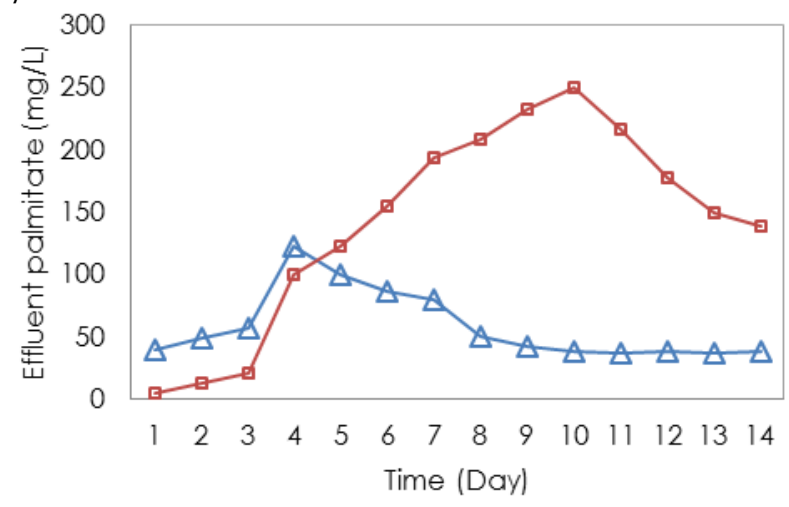

$\triangle \mathrm{LAB} \quad \square \mathrm{NAB}$

Figure 3 The profile of (a) oleate and (b) palmitate of NAB and $L A B$ during the start-up operation

In Figure 3 , it can be seen that the LCFA profile for both reactors depicted that the most abundant LCFA were palmitate and oleate when the concentration of both LCFA were relatively higher in 
inhibited reactors (NAB) as compared to noninhibited reactor $(L A B)$ for the entire of start-up process. In this study, palmitate and oleate were the main LCFA that accumulated and maintain at higher concentration in inhibited than non-inhibited reactor. Palmitate acid is the primary product from oleate degradation phenomenon obtained in this study is similar as what has been observed from previous study $[6,18]$.

The concentration of oleate accumulated in NAB were within the same range $(100 \mathrm{mg} / \mathrm{L}-200 \mathrm{mg} / \mathrm{L})$ as reported by [16] for inhibition had occurred during lag phase. Angelidaki \& Ahring (1992) also reported the similar range of oleate concentration that was inhibited the thermophilic anaerobic digestion of cattle manure [20]. Stearate and myristate was detected in very low level and the accumulation values were not significantly high as palmitate in both reactors (Results not shown). No significant increment in concentration recorded for stearate and myristate indicated that fast and easy mineralized process conversion of both LCFA and that the limiting factor was not from this conversion [15].

\subsection{Semi-continuous Feeding Operation}

During steady-state condition, it was observed that the methane composition, methane production rate and methane yield increased with increasing OLR from $1.3 \mathrm{gCOD/L}$.day until $2.2 \mathrm{gCOD} / \mathrm{L}$.day for both reactors as depicted in Figure $4(a, b, c)$. Later, a downtrend methane production was observed for OLR from $2.5 \mathrm{gCOD/L.day} \mathrm{to} 3.6 \mathrm{gCOD/L.day} \mathrm{for} \mathrm{all}$ reactors indicated a decreased performance of all reactors.

Overall performance of steady state condition in all reactors depicted that the effectiveness of methanogen activities reached its maximum efficiency at OLR 2.2 gCOD/L.day. At this stage of stable condition, the average maximum methane composition was recorded highest in $L A B(71 \%)$ than $N A B(60 \%)$. While for methane production rate, average maximum values recorded for $L A B$ and $N A B$ was 0.455 and $0.269 \quad \mathrm{LCH}_{4} / \mathrm{L}$.day, respectively. Furthermore, in agreement with methane composition and production rate performance, methane yield for all reactors were also recorded its average maximum values at OLR of $2.2 \mathrm{gCOD/L.day.}$ The value of methane yield evaluated for $L A B$ is 0.22 $\mathrm{LCH}_{4} / \mathrm{gCODremoved}$ and for $\mathrm{NAB}$ is 0.14 $\mathrm{LCH}_{4} / \mathrm{gCOD}$ removed.

Easily converted to biogas in LAB during start-up had induced and affected the overall methane production when higher values in $L A B$ than $N A B$ reactor were observed. This signifies that acclimated biomass to lipid in $L A B$ has higher resistance to lipid toxicity and can improved the production rate. An increase in OLR of 2.5 gCOD/L.day onwards had decreased the value of methane composition, production rate and methane yield. The reduction of these values maybe caused by organic wash out due to semi-continuous feeding and no sludge recycle implemented that may reduce the tolerance to the substrate $[1,21]$.

(a)

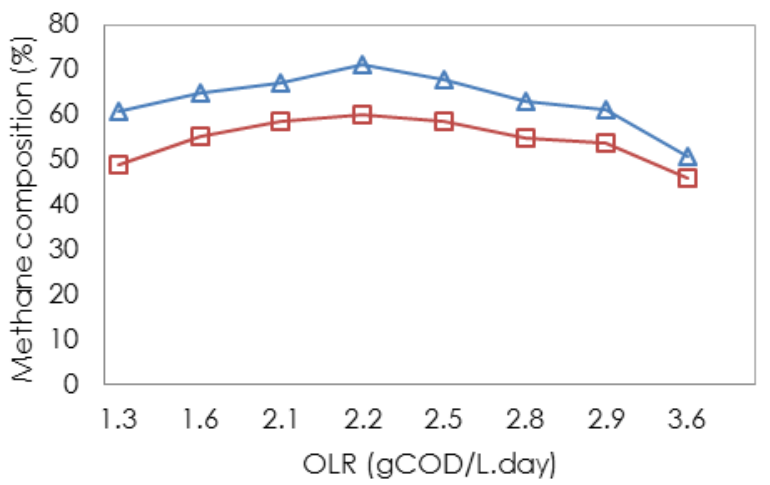

(b)

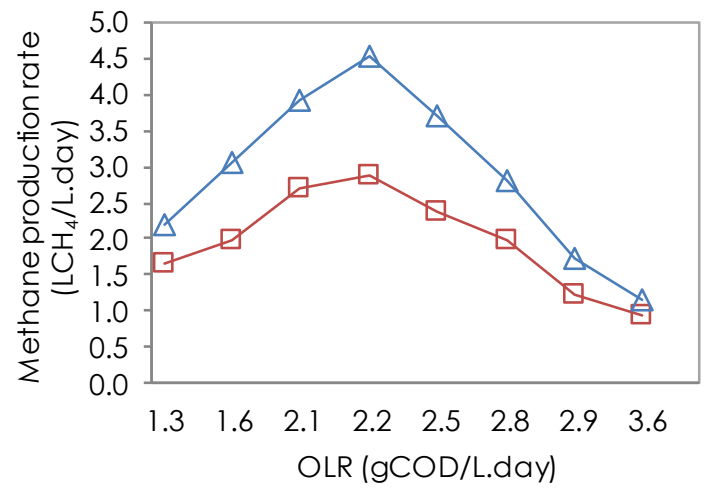

(c)

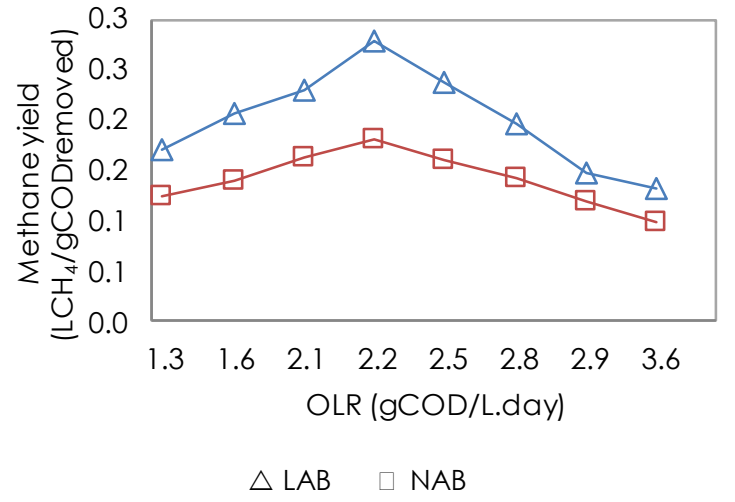

Figure 4 The profile of (a) methane composition; (b) methane production rate and; (c) methane yield in NAB and LAB during steady state condition

Data on methane composition and the occurrence of lag phase in this study were comparable to those reported by [22]. It can be seen that the methane production is retarded in higher concentration of inhibitor and the duration of lag phase also increase. [17] demonstrated higher 
concentration of oleate $(900 \mathrm{mg} / \mathrm{L})$ evaluated that shock load do not improves methane production hence no methane production were recorded for the entire experiments even though acclimated inoculum was used. The experiment was stop after 21 days duration and suggested that the accumulation of LCFA is a critical factor to be considered when dealing with oily effluents. In order to improves the performance of waste vegetable oil, [7] observed the potential of using acclimated biomass (sludge from hotel, restaurants and catering waste anaerobic treatment) could improves $3 \%$ methane production regardless any LCFA concentration that inhibit the system. However, the occurrence of lag phase indicated that inhibition occurred at the initial stage of the study. The comparison between methane yields cannot be made so far as this system has not been applied for any continuous stir tank reactor (CSTR) in the literature studies.

\subsection{CONCLUSION}

The existing results demonstrate that the inoculum previously adapted to LCFA and as well as the control operating condition can lead to better outcomes when anaerobic digestion of oily waste is concerned. By using acclimated inoculum, 15\% methane production composition improvement was observed with biogas containing $71 \%$ methane and methane yield of $0.22 \quad \mathrm{LCH}_{4} / \mathrm{gCOD}$ removed were achieved. Efficient performance of acclimated reactor (LAB) was achieved at OLR of 2.2 gCOD/L.day. The use of acclimated inoculum had no observation of lag phase during the start-up stage and is consider a promising strategy to accelerate the start-up process and thus improve the overall performance of anaerobic digestion from GTW.

\section{References}

[1] Alves, M. M., Pereira, M. A., Sousa, D. Z., Cavaleiro, A. J. Picavet, M., Smidt, H., \& Stams, A. J. M. 2009. Waste Lipids to Energy: How to Optimize Methane Production from Long-chain Fatty Acids (LCFA). Microbial Biotechnology. 2(5): 538-50.

[2] Neves, L., Pereira, M. A., Mota, M., \& Alves, M. M. 2009. Detection and Quantification of Long Chain Fatty Acids in Liquid and Solid Samples and Its Relevance to Understand Anaerobic Digestion of Lipids. Bioresource Technology. 100: 91-96.

[3] Pereira, M. a, Sousa, D. Z., Mota, M., \& Alves, M. M. 2004 Mineralization of LCFA Associated with Anaerobic Sludge: Kinetics, Enhancement of Methanogenic Activity, and Effect of VFA. Biotechnology and Bioengineering. 88(4): 502-11.

[4] Gonçalves, M. R., Costa, J. C., Marques, I. P., \& Alves, M. M. 2012. Strategies for Lipids and Phenolics Degradation in the Anaerobic Treatment of Olive Mill Wastewater. Water Research. 46(6): 1684-92.

[5] Rinzema, A., Boone, M., van Knippenberg, K., \& Lettinga, G. 1994. Bactericidal Effect of Long Chain Fatty Acids in Anaerobic Digestion. Water Environment Research. 66(1): 40-49.
[6] Cirne, D. G., Paloumet, X., Bjornsson, L., Alves, M. M., \& Mattiasson, B. 2007. Anaerobic Digestion of Lipid-Rich Waste - Effects of Lipid Concentration. Renewable Energy. 32(6): 965-975.

[7] Hidalgo, D., \& Martín-Marroquín, J. M. 2014. Effects of Inoculum Source and Co-digestion Strategies on Anaerobic Digestion of Residues Generated in the Treatment of Waste Vegetable Oils. Journal of Environmental Management. 142: 17-22.

[8] Chan, Y. J., Chong, M. F., \& Law, C. L. 2012. Start-up, Steady State Performance and Kinetic Evaluation of a Thermophilic Integrated Anaerobic-Aerobic Bioreactor (IAAB). Bioresource Technology. 125: 145-57.

[9] Li, C., Champagne, P., \& Anderson, B. C. 2011. Evaluating and Modeling Biogas Production from Municipal Fat, Oil and Grease and Synthetic Kitchen Waste in Anaerobic Co-Digestions. Bioresource Technology. 102(20): 94719480.

[10] Mobarak-Qamsari, E., Kasra-Kermanshahi, R., Nosrati, M., \& Amani, T. 2012. Enzymatic Pre-hydrolysis of High Fat Content Dairy Wastewater as a Pre-treatment for Anaerobic Digestion. International Journal Environmental Research. 6(2): 475-480.

[11] Leal, M. C. M. R., Freire, D. M. G., Cammarota, M. C., \& Sant' Anna Jr., G. L. 2006. Effect of Enzymatic Hydrolysis on Anaerobic Treatment of Dairy Wastewater. Process Biochemistry. 41 (5): 1173-1178.

[12] Baharuddin, A. S., Hock, L. S., Yusof, M. Z., Abdul, N. A., Shah, U., Hassan, M. A., Shirai, Y. 2010. Effects of Palm Oil Mill Effluent (POME) Anaerobic Sludge from 500 M 3 of Closed Anaerobic Methane Digested Tank on PressedShredded Empty Fruit Bunch (EFB) Composting Process. African Journal of Biotechnology. 9(16): 2427-2436.

[13] Alves, M. M., Mota Vieira, J. A., Álvares Pereira, R. M. Pereira, M. A., Mota, M. 2001. Effect of Lipids and Oleic Acid on Biomass Development in Anaerobic Fixed-bed Reactors. Part I: Biofilm Growth and Activity. Water Res. 35: 255-263.

[14] Neczaj, E., Bien, J., Grosser, A., Worwag, M., \& Kacprzak, M. 2012. Anaerobic Treatment of Sewage Sludge and Grease Trap Sludge in Continuous Co-digestion. Global NEST Journal. 14(2): 141-148.

[15] Neves, L., Ferreira, R., \& Oliveira, R. 2010. Influence of Innoculum Acclimation in the Biodegradation Rate and Estimated Biodegradbility of Cow Manure, Food Waste and Oil. Environmental Engineering and Management Journal. 9(3): 327-334.

[16] Griffin, M. E., McMahon, K. D., Mackie, R. I., \& Raskin, L. 1998. Methanogenic Population Dynamics during Start-up of Anaerobic Digesters Treating Municipal Solid Waste and Biosolids. Biotechnology and Bioengineering. 57(3): 342-55.

[17] Cavaleiro, A. J., Pereira, M. A., \& Alves, M. 2008. Enhancement of Methane Production from Long Chain Fatty Acid Based Effluents. Bioresource Technology. 99(10): 4086-95

[18] Pereira, M. a, Pires, O. C., Mota, M., \& Alves, M. M. 2002. Anaerobic Degradation of Oleic Acid by Suspended and Granular Sludge: Identification of Palmitic Acid as a Key Intermediate. Water Science and Technology: A Journal of the International Association on Water Pollution Research. 45(10): 139-44.

[19] Palatsi, J., Laureni, M., Andrés, M. V. Flotats, X., Nielsen, H. B., \& Angelidaki, I. 2009. Strategies for Recovering Inhibition Caused by Long Chain Fatty Acids on Anaerobic Thermophilic Biogas Reactors. Bioresource Technology. 100(20): 4588-96.

[20] Angelidaki, I., \& Ahring, B. K. 1992. Effects of Free LongChain Fatty Acids on Thermophilic Anaerobic Digestion. Applied Microbiology and Biotechnology. 37: 808-812.

[21] Long, J. H., Aziz, T. N., De Los Reyes III, F. L., \& Ducoste, J. J. 2011. Anaerobic Co-digestion of Fat, Oil, and Grease (FOG): A Review of Gas Production and Process Limitations. Process Safety and Environmental Protection. $90(3):$ 231-245. 
[22] Pereira, M. A., Mota, M., \& Alves, M. M. 2001. Degradation of Oleic Acid in Anaerobic Filters: The Effect of Inoculum
Acclimatization and Biomass Recirculation. Water Environment Research. 73(5): 1-8. 